\title{
THE CREATIVE INDUSTRY AS A FACTOR IN THE DEVELOPMENT OF THE ECONOMY: DISSEMINATION OF EUROPEAN EXPERIENCE IN THE COUNTRIES WITH ECONOMIES IN TRANSITION
}

\author{
Yuriy BILAN ${ }^{1}{ }^{*}$, Tetyana VASILYEVA ${ }^{2}$, Olena KRYKLII ${ }^{3}$, \\ Gulbarshyn SHILIMBETOVA ${ }^{4}$ \\ ${ }^{1}$ Tomas Bata University in Zlín, Faculty of Management and Economics, Centre of Applied Economic \\ Research, nám. T. G. Masaryka 5555, 76001 Zlín, Czech Republic \\ ${ }^{2}$ Sumy State University, Oleg Balatskyi Academic and Research Institute of Finance, Economics and \\ Management 2, Rymskogo-Korsakova Str., Main Building, 40007 Sumy, Ukraine \\ ${ }^{3}$ Sumy State University, Academic and Research Institute of Business Technologies "UAB", \\ Department of Finance, Banking and Insurance 2, Rymskogo-Korsakova Str., \\ Main Building, 40007 Sumy, Ukraine \\ ${ }^{4}$ Al-Farabi Kazakh National University, High School of Economics and Business, Economics Institute, \\ 71 al-Farabi Ave., Almaty, Republic of Kazakhstan, 050040
}

Received 07 January 2019; accepted 08 March 2019

\begin{abstract}
The purpose of this article is to determine the possibility of using the experience of European countries in the development of the creative industry as a driving force for economic growth for the economies in transition. The authors studied the concept of the creative industry, existing models of classification of sub-sectors of the creative economy. The article analyses data on the world trends in the development of the creative industry and features of these processes in the economies in transition. Based on the results obtained, the key triggers that should be influenced by government regulation in economies in transition are: ensuring access to finance, ensuring an effective system of education at all levels to ensure the availability of skilled labour and literacy consumers of creative products, availability of high-quality infrastructure and regulatory system. Proceeding from this, recommendations for the development of creative industry in the economies in transition structured in terms of the key stakeholders: government, local government (regions and cities), higher educational institutions, creative industry, and other business representatives.
\end{abstract}

Keywords: classification of creative industries, creative economy, creative industries, economies in transition.

\section{Introduction}

In recent years, the need for thinking, adapting, and exploring the opportunities and prospects for creative industries (CIs) in countries with transitional economies (CTEs) has increased significantly. It is primarily related to the presence of significant shortcomings in the

${ }^{\star}$ Corresponding author. E-mail: yuriy_bilan@yahoo.co.uk

This is an Open Access article distributed under the terms of the Creative Commons Attribution License (http://creativecommons. org/licenses/by/4.0/), which permits unrestricted use, distribution, and reproduction in any medium, provided the original author and source are credited. 
economic models (EMs) of a number of CTEs, particularly post-Soviet, causing insufficient rates of their economic development and gap behind both the indicators of developed countries (DCs) of the world and a number of CTEs. The deadline for the transition to a market economy most transition countries at the moment is uncertain.

One of the key reasons for this is the lack of effectiveness of structural economic reforms, which in the era of scientific and technological transformations, mass digitization and increasing the role of intellectual property, should ensure the formation of an innovative EM (Balcerzak \& Pietrzak, 2017; Madrak-Grochowska, 2015; Wierzbicka, 2018; Nwaiwu, 2018). This model should be based on the development of the quaternary sector of the economy, involving the generation and dissemination of knowledge and information, including through the development of CIs (Spitsin, Mikhalchuk, Chistyakova, Spitsyna, \& Pavlova, 2018). As productive sectors of the creative economy (CE), CIs produce goods and services using creativity and intellectual capital as "primary inputs" and therefore proposes clean, green and sustainable economic models (García Lorente, 2016).

Creating new areas of economic activity, the CIs create the conditions for economic growth and diversification, providing solutions for single-industry towns and rural settlements, expanding the inclusion of small and medium-sized businesses and become the basis for the transformation of economies of CTEs.

The CIs contributes $6,1 \%$ to the world gross domestic product (GDP), between $2 \%$ and $7 \%$ to the GDP of national economies, and 29.5 million jobs worldwide. Thus, in the global economy, a GDP of $\$ 4.300$ trillion is generated and the exportation of creative and cultural goods and services reach $\$ 646$ trillion of which $82 \%$ of countries with developed economies (CDEs) (García Lorente, 2016).

The study of the experience of CDEs in this area testifies not only to lost profits but also to the continuing huge potential of CI for the economic growth (EG) of countries with CTEs as well as individual cities and regions.

Based on this, the purpose of the article is to determine the possibility of using the experience of European countries in the development of CIs as a driver of EG and sustainable development for CTEs.

\section{Previous research on the subject}

To achieve the goal of the study, the authors studied the concept of the CI. We agree with the statement of Elena V. Zelentsova (2008), who determined that CIs are a synthetic phenomenon that closely linked culture, economics and social policy. These types of activity are largely contradictory: a free search for artists, focused on values such as spirituality, selfexpression, beauty, etc.; a pragmatic business initiative, focused on the personal and corporate benefits; state and regional governance, focused on strengthening and development of the nation, country, territory (Mitkus \& Maditinos, 2017).

Because of the complexity of this phenomenon, it follows that specialists in various fields explore the problems of CIs: economics, sociology, cultural studies, management and urban studies. 
Since the first mention of the concept of "cultural industry (CUI)" in 1947 by Max Horkheimer and Theodor W. Adorno (2009), interest in this topic has steadily increased. These scientists have explored the concept in the context of the threats posed by the industrialization of culture. In their opinion, the CUI does not carry the values for a person, is not aimed at spiritual enrichment and enlightenment, being, in fact, an entertainment business. This is because it produces uniform, standardized innovations in the fields of art, painting, literature and cinema. At the same time, generating false needs, the CUI turns the consumer into a passive man, indifferent even to his own economic position, no matter how hard it is.

The sociologists of the French School (Morin, 1962; Miège, 1979) made a significant contribution to the development of the concept of CUIs in the second half of the 20th century.

A special place in the theoretical studies of s occupies the work of Bernard Miège (1979). In particular, he was the first to classify CUIs depending on how they create exchange value. Miège (1979) also began exploring the various sectors of the CUIs in accordance with the types of materials and tools they use.

Later, as part of rethinking the future of post-industrial countries (primarily, Great Britain), the definition "CUIs" was changed to "CIs". This contributed to the strengthening of ideas, those CIs will help to improve the economy of DCs after many industries transferred to the countries of Southeast Asia.

The subsequent works can be divided into the following main groups, corresponding to the stages of formation and transformation of the phenomenon being studied.

John Howkins (2001), Richard Florida (2005a, 2005b, 2014), Terry Flew (2005), Ann R. Markusen, Gregory H. Wassall, Douglas DeNatale and Randy Cohen (2008), Mark J. Stern and Susan C. Seifert (2008), Anna Zachorowska-Mazurkiewicz and Tomasz Sierotowicz (2017) and Beata Ślusarczyk (2018) have formed frame the concept of a CE, singled out the theme of creativity as a system-forming factor of social development.

The second group is research directly devoted to the history, characteristics and specifics of CIs. An important role is occupied by works Stuart Cunningham (2002), Nicholas Garnham (2005), John Hartley (2005), David Hesmondhalgh and Andy C. Pratt (2005), Susan Galloway and Stewart Dunlop (2007), Jason Potts and Cunningham (2008), Peter John Higgs, Cunningham and Hasan Bakhshi (2008), Higgs and Cunningham (2008), David Throsby (2008), Toby Miller (2009), Justin O’Connor (2009, 2010, 2011), Flew and Cunningham (2010), Flew (2005, 2012). Bruno Miguel Teixeira Bento Pires (2012), David Hesmondhalgh (2015).

The third array of publications is devoted to the role of CIs in the development of cities and regions (Landry \& Bianchini, 1995; Hall, 2000; Florida, 2005a, 2014; Landry 2005, 2008, 2011; Scott, 2006; Pratt, 2008, 2010, 2011; Bontje \& Musterd, 2009; Cooke \& Lazzeretti, 2008; Evans, 2009; Foord, 2008; O’Connor, 2009; Comunian, Chapain, \& Clifton, 2010; Krätke, 2010; Sułkowski, 2012; Anatoliivna Vasylieva \& Kas'yanenko, 2013; Godlewska-Majkowska, Komor, \& Typa, 2016; Štefko \& Steffek, 2017; Żelazny, 2017).

The fourth group of works is devoted to the study of the development of CIs in the countries of the world with differentiation by region and level of economic development. Of particular importance are works on the development of CIs in CDEs in the context of using their experience for countries in transition (Yusuf \& Nabeshima, 2005; Gibson, 2006; 
Higgs, Cunningham, \& Pagan, 2007, Higgs, Cunningham, \& Bakhshi, 2008; O’Connor, 2009; Boix, Lazzeretti, Capone, Propris, de, \& Sánchez, 2013; Nathan, Pratt, \& Rincon-Aznar, 2015; Daubaraitė \& Startiené, 2015; Stasiulis, 2017; Lazzeretti, Capone, \& Innocenti, 2018; Vasilyeva, Lyeonov, Adamičková, \& Bagmet, 2018a; Vasilyeva, Lyeonov, Lyulyov, \& Kyrychenko, 2018b; Lyeonov, Vasylieva, \& Lyulyov, 2018).

A separate line of research in this group is devoted to the study of the specificity of the influence of CIs in the economic systems of CTEs.

Jaka Primorac (2014) analyzes the current state and the factors that, on the macro level, hinder the development of CIs and perspectives of CIs in Southeastern Europe (SEE). The author shows how that the situation in that region is still very diverse and that the conditions for the further enhancement of CIs are still not developed. Taking into account the heterogenic situation throughout the SEE region the author outlines the necessity for the locally-founded policies for CIs that would be created within the framework of strategies for sustainable development.

The research results of the Rahman Nurković (2015) revealed that the CIs played a significant role in the systemic transformation of the post-socialist urban settlements of Bosnia and Herzegovina (BaH). It was determined that the presence of highly qualified personnel, the presence of a local initiative for the development of culture and the promotion of the economic and social attractiveness of European cities played a positive role in these processes. At the same time, the entrepreneurial business approach to creativity in $\mathrm{BaH}$ is at the incubation stage and is often frozen due to complex state administration.

Christiaan De Beukelaer and Galina Koretskaya (2016) analyzes the current state, challenges, and strategies of development of CIs in Kazakhstan. The authors revealed that between 2004 and 2012 the Kazakhstan creative goods (CGs) trade deficit increased fourfold. While this show the industries are currently not performing well internationally, it also indicates that CGs consumption within the country is significant and growing. They determined that the CIs of Kazakhstan have great potential for development, despite the weak level of state support, imperfect legislation, lack of infrastructure and human capacity.

Cristina Farinha (2018a, 2018b, 2018c, 2018d, 2018e, 2018f) analyzes the development of cultural and creative industries (CCIs) in the countries of the European Union (EU) Eastern Partnership: Armenia, Azerbaijan, Belarus, Georgia, Moldova and Ukraine, but most importantly, she provides a country-specific view on challenges and tailored recommendations for CCIs in them.

An analytical report "Education and Creative Industry in the Mirror of International and Domestic Practices" (Analiticheskiy tsentr pri pravitelstve Rossiyskoy federatsii, 2017) characterizes the development of the CI in Russia. The study determined that, now, the contribution of CIs to Russia's EG is insignificant. "At the moment (2017) the creative industry is estimated $0,5 \%$ of the GDP, but by 2025 its share may increase several-fold" (2017). It was concluded that the CI in Russia has a huge potential for growth, which can be realized with the development of personal potential and systemic state support.

CIs in Ukraine studied Pavlo T. Bubenko, Sergiy Luk'yanets (2014), Igor' Turs'kij (2016), Alla Kholodnitskaya (2018), Iryna V. Skavronska (2017). The works of these scientists re- 
vealed that, despite Ukraine's significant potential for the development of CIs, the lack of infrastructure, the insufficiency of government support, and the lack of protection of intellectual property do not allow it to be fully realized. Despite the significant differentiation of internal conditions affecting the development of CIs in CTEs, several factors hindering their development are common to them. This is the need for improving the state support system, the regulatory framework in terms of the protection of intellectual property rights, the formation of the necessary infrastructure and system of financing.

A significant contribution to the development of the concept of CE and CIs was played by studies of the United Nations Conference on Trade and Development (UNCTAD) and the United Nations Educational, Scientific and Cultural Organization (UNESCO).

A systematic assessment of the global turnover of cultural goods and services was first given in the UNCTAD in 2008 CE report (2008). The 2010 UNCTAD CE report determined that sector had become a important component of EG, employment, trade, and innovation in most advanced economies (2010). At the same time, most developing countries (DECs) did not use their potential for the development of CIs due to weak spots in both state politics and the business environment. The UNCTAD report, "Creative Economy Outlook and Country Profiles: Trends in International Trade in Creative Industries" (2015) describes the current state of international trade in CGs and services worldwide and in 71 countries. Statistics confirm that there are potential opportunities for CTEs and DECs to increase production and export of creative products (CPs).

UNESCO researches in the field of creative economics have a systemic nature and contain an explanation of the concepts of "creative economics", "CUIs", "CIs", "cultural creativity and innovations". UNESCO Creative economy report (2013) contains a formed classification of CCIs, systematized indicators the effectiveness and success of the CCIs. The report examines critical factors that need to be considered when making decisions and developing political strategies and programs to create new ways of developing a local CE.

That studies have formed a conceptual framework for the formation of public policy and policy recommendations in the field of cultural development, CCIs for many countries around the world.

In 2014, the auditing and consulting company Ernst \& Young analyzed the cultural and creative markets in the EU. The study identified the main factors that will influence the global evolution of the CCIs and participants and strategies to stimulate EG, youth employment and strengthening Europe's position on a global scale (ey.com, 2014).

In 2015, Ernst \& Young mapped the CE in the world. A rating of CIs in terms of profitability, the share of creative income in GDP and employment was established for five regions of the world: North America (NA); Europe; Asia-Pacific (A-P); Latin America (LA) and the Caribbean; Africa and the Middle East (ME) (ey.com, 2015).

From this study, we can conclude that the CIs have not yet received due recognition of their role in the development of transition economies. At the same time, the fullest use of their potential will make it possible to move from industrial and commodity economies to creative ones, which is especially important for CTEs. 


\section{Methodology}

A three-stage approach was designed to achieve the objectives of the research. The first stage involves statistical data analysis on the world trends in the development of the CIs and features of these processes in the CTEs. The study employs time series data, specifically panel data covering the period of 2002 to 2015, in CTEs (countries of the Commonwealth of Independent States and Georgia, South-Eastern Europe), which was obtained from the UNCTAD Data centre of the creative economy (United Nations Conference on Trade and Development STAT, 2018).

Secondly, is the theoretical approach, contains the systematic, logical and comparative analysis and synthesis of scientific literature on concepts of CIs and their development with special interest to their influence on the economic and non-economic indicators of the development of countries.

At the third stage, on the basis of the obtained theoretical results and the results of statistical data analysis, the generalization and final results visualization were carried out.

\section{Results of the research, and discussion with interpretation of results obtained}

CIs are a dynamic sector that has been developing in recent years. In a study conducted by Ernst \& Young analysed 11 CCIs in Europe, NA, LA, Africa, the ME and the South Pacific region (ey.com, 2015). It has combined generated $\$ 2.250$ billion (bn) in revenues ( $3 \%$ of world GDP). The highest earners were television ( $\$ 477 \mathrm{bn}$ ), newspapers and magazines ( $\$ 354 \mathrm{bn}$ ) and visual arts ( $\$ 391 \mathrm{bn})$. CCI generated 29.5 million jobs, which employ about $1 \%$ of the world's active population. The top three employers are visual arts (6.73 million employees), books (3.67 million) and music (3.98 million).

The economic role of CCIs in different regions is different (Table 1).

From the Table 1, it can be concluded that even though the highest rates of income from CIs and the number of people employed in the CE are in A-P countries, the highest share of creative income in GDP belongs in United States (US) and Canada.

The highest share of the creative class in Singapore is about $52 \%$, Korea is $47 \%$, Canada is $43 \%$, the US is $38 \%$, Australia is $45 \%$, India is slightly more than $30 \%$, Malaysia is $27 \%$, and the Philippines is $22 \%$. These countries occupy high positions in the ranking of countries on the Global Creativity Index (GCI).

An important economic indicator of CIs is the international trade in CGs. The global market for CGs in 2014 amounted to $\$ 579$ bn, compared with $\$ 210$ bn in 2002. The year 2015 was characterized by a fall in the volume of exports of CGs, primarily due to a decrease in this indicator in DECs (Figure 1a).

From 2002 to 2015, the export of CGs from DCs increased, while export revenues increased from $\$ 122$ to $\$ 241$ bn. Because the export of CGs in DECs in this period grew at a faster rate, the share of DCs in world exports of this category of goods decreased from 59 to 47\% (Figure 1b).

Among DCs, Europe is the largest exporter of CGs, although its share has declined over the period of the study. In 2015, the five largest producers of CGs included France, Italy, 
Table 1. Characteristics of the development of cultural and creatives in the regions of the world market leaders (source: created by authors (based on ey.com, 2015))

\begin{tabular}{|c|c|c|}
\hline Region & Key indicators & Specifications \\
\hline Asia-Pacific & $\begin{array}{l}\$ 743 \text { billion of revenues (33\% } \\
\text { of global cultural and creative } \\
\text { industries revenues); } \\
3 \% \text { of regional gross } \\
\text { domestic product; } \\
12.7 \text { million jobs ( } 43 \% \text { of } \\
\text { total cultural and creative } \\
\text { industries jobs). }\end{array}$ & 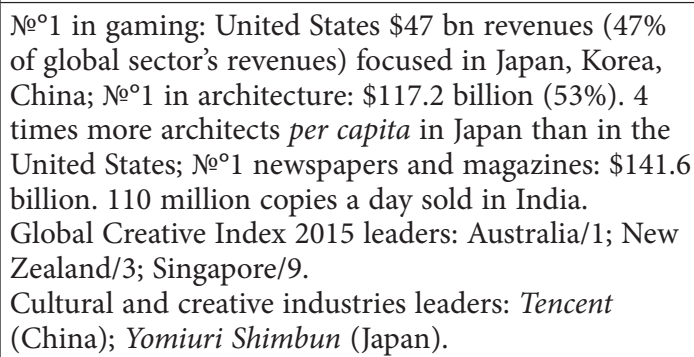 \\
\hline Europe & $\begin{array}{l}\$ 709 \text { billion of revenues (32\% } \\
\text { of the global cultural and } \\
\text { creative industries revenues). } \\
3 \% \text { of regional gross } \\
\text { domestic product; } \\
\text { The sector is its third-largest } \\
\text { employer: } 7.7 \text { million jobs } \\
\text { (26\% of total cultural and } \\
\text { creative industries jobs). }\end{array}$ & $\begin{array}{l}\text { № }{ }^{\circ} \text { in advertising: } \$ 143.7 \text { billion revenues ( } 50 \% \text { of } \\
\text { global sector's revenues). } \\
\text { № } 1 \text { in books: } \$ 52.5 \text { billion revenues (37\%). } \\
\text { Attracting } 52 \% \text { of international tourists. Seven of the } \\
10 \text { most visited museums in the world are European } \\
\text { (three in Paris, two in London) and } 30 \text { of the } 69 \\
\text { United Nations Educational, Scientific and Cultural } \\
\text { Organization "Creative Cities" are European. } \\
\text { Global Creative Index } 2015 \text { leaders: Finland/5; } \\
\text { Sweden/7; Iceland/8; Netherlands/10. } \\
\text { Cultural and creative industries leaders: WPP plc, } \\
\text { Publicis Groupe, Pearson, Axel Springer, Vivendi, } \\
\text { Universal Music Group, Ubisoft, Hachette Book Group. }\end{array}$ \\
\hline NA & $\begin{array}{l}\$ 620 \text { billion ( } 28 \% \text { of global } \\
\text { cultural and creative } \\
\text { industries revenues); } \\
3.3 \% \text { of regional gross } \\
\text { domestic products; } \\
4.7 \text { million jobs (16\% of } \\
\text { total cultural and creative } \\
\text { industries jobs). }\end{array}$ & 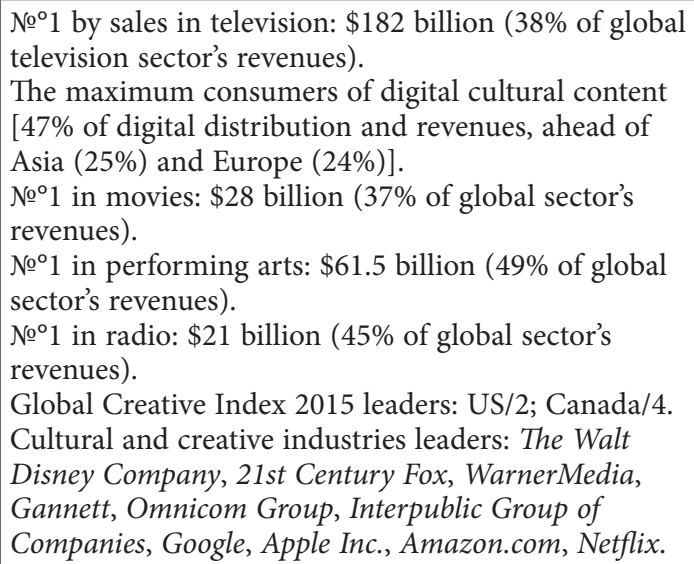 \\
\hline
\end{tabular}

United Kingdom (UK), Germany, and Switzerland. The industry structure of exports of CIs from Europe is dominated by design, which includes such types of goods and services as architectural solutions, designer clothes, jewelry, home furnishings, toys.

From 2002 to 2015, exports of CGs from DECs increased, while export revenues increased from 84 to 265 bn US dollars. In this group, China is the largest exporter of CGs. In 2015, the top five exporters were also Hong Kong, China, India, Turkey and South Korea. When analyzing the indicators of the development of CIs in DECs, we consider it necessary to take into account the results of the research by Beukelaer (2014). He focused on refining 

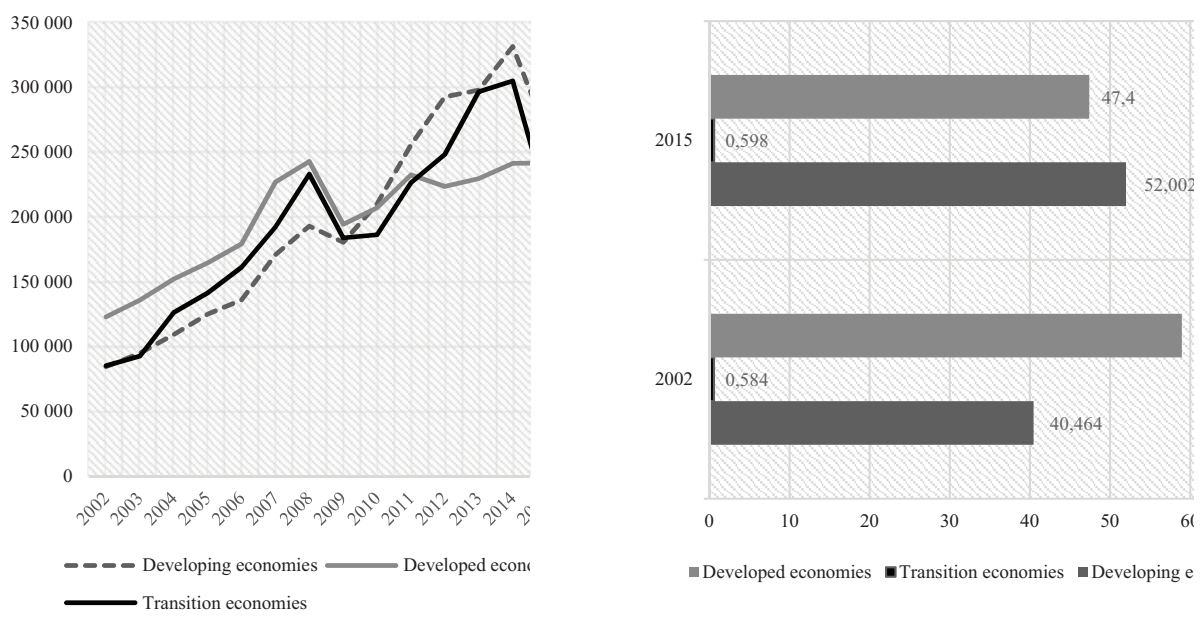

Figure 1. Export of creative goods by economic group, 2002-2015: a - values, b - shares, \% (source: created by authors (based on United Nations Conference on Trade and Development STAT, 2018)

the statistical data characterizing the development of CIs in DECs. The author offers a more balanced view of the classification of countries by level of economic development in terms of in-depth disaggregation of a group of DECs for analysing CIs. The need for this is confirmed by the fact that one "DEC" (China) is the largest exporter of CGs in the world $(25.51 \%$ in 2010), but 49 "least developed DCs" make up only $0.11 \%$ of the export of CGs, while they make up 880 million people (or about $12 \%$ of the world's population).

CTEs do not play an important role in international trade in CIs. Their share in world trade in services during the period of analysis did not exceed $1 \%$. The main contribution to the export performance of CIs in transition economies is made by countries such as Belarus, $\mathrm{BaH}$, Russian Federation (RF), and Ukraine (Figure 2).

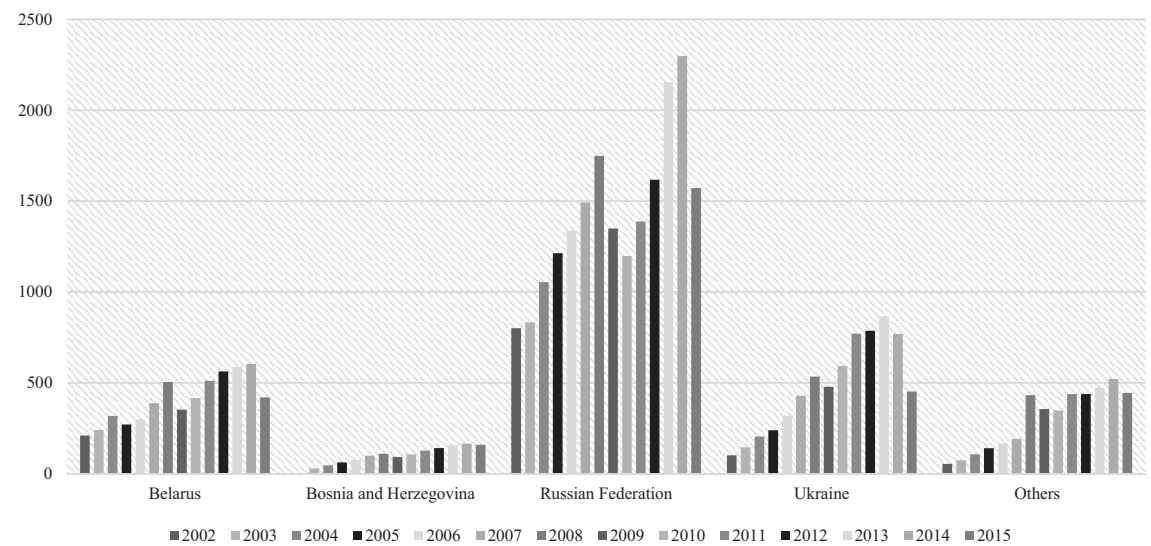

Figure 2. Values exports of creative goods in countries with transition economies, 2002-2015, $\$$ million (source: created by authors (based on United Nations Conference on Trade and Development STAT, 2018)) 
The largest share in the export of CGs from CTEs has publishing, whose share in the period of analysis fluctuated at the level of $3 \%$ of the world export of CGs.

For the development of CIs, it is important to understand the specifics of those goods that are in demand in the global market. Indicate that in all countries except the RF, the structure of the export of CGs is non-diversified with the dominance of design. The structure of the export of CGs of the RF is quite diversified, with a predominance of publishing, while over the period of the study, the importance of design and audiovisuals has significantly increased. At the same time, the results of the study indicate that a number of CTEs have sufficient internal potential for the development of CIs (Table 2).

Table 2. Dynamics of indicators reflecting the potential for the development of creative industries in economies in transition (source: created by authors (based on Florida, Mellander, \& King, 2015; Dutta, Lanvin, \& Wunsch-Vincent, 2018)

\begin{tabular}{|c|c|c|c|c|c|c|c|}
\hline \multirow{2}{*}{ Country } & \multicolumn{3}{|c|}{$\begin{array}{c}\text { Rank of components of } \\
\text { Global Creativity Index } 2015\end{array}$} & \multirow{2}{*}{$\begin{array}{c}\text { Rank in } \\
\text { Global } \\
\text { Creativity } \\
\text { Index } 2015\end{array}$} & \multicolumn{2}{|c|}{$\begin{array}{l}\text { Rank of Sub-Index of } \\
\text { Global Innovation Index } \\
2018\end{array}$} & \multirow{2}{*}{$\begin{array}{c}\text { Rank in } \\
\text { Global } \\
\text { Innovation } \\
\text { Index } \\
2018\end{array}$} \\
\hline & $\begin{array}{l}\text { Rank in } \\
\text { technol- } \\
\text { ogy }\end{array}$ & $\begin{array}{l}\text { Rank } \\
\text { in } \\
\text { talent }\end{array}$ & $\begin{array}{l}\text { Rank in } \\
\text { tolerance }\end{array}$ & & $\begin{array}{l}\text { The Input } \\
\text { Sub-Index }\end{array}$ & $\begin{array}{l}\text { The Output } \\
\text { Sub-Index }\end{array}$ & \\
\hline Belarus & 41 & 8 & 97 & 37 & 60 & 110 & 86 \\
\hline $\begin{array}{l}\text { Russian } \\
\text { Federation }\end{array}$ & 22 & 15 & 123 & 38 & 43 & 56 & 46 \\
\hline Ukraine & 43 & 24 & 105 & 45 & 75 & 35 & 43 \\
\hline Montenegro & 51 & 34 & 83 & 46 & 51 & 55 & 52 \\
\hline Serbia & 70 & 45 & 58 & 54 & 56 & 58 & 55 \\
\hline Georgia & 35 & 82 & 78 & 64 & 53 & 62 & 59 \\
\hline $\begin{array}{l}\text { Republic of } \\
\text { Macedonia }\end{array}$ & 76 & 63 & 70 & 74 & 71 & 93 & 84 \\
\hline Kazakhstan & 72 & 54 & 54 & 84 & 55 & 91 & 74 \\
\hline Uzbekistan & 74 & 111 & 64 & 100 & $\mathrm{n} / \mathrm{a}$ & $\mathrm{n} / \mathrm{a}$ & $\mathrm{n} / \mathrm{a}$ \\
\hline Armenia & 83 & 50 & 133 & 103 & 94 & 50 & 68 \\
\hline Moldova & 85 & 57 & 128 & 105 & 79 & 37 & 48 \\
\hline $\begin{array}{l}\text { Bosnia and } \\
\text { Herzegovina }\end{array}$ & 77 & 70 & 119 & 108 & 68 & 82 & 77 \\
\hline Azerbaijan & 98 & 78 & 92 & 110 & 76 & 87 & 82 \\
\hline Kyrgyzstan & 100 & 74 & 94 & 111 & 85 & 101 & 94 \\
\hline Tajikistan & 106 & 90 & 85 & 114 & 104 & 88 & 101 \\
\hline Albania & 83 & 90 & 118 & 116 & 69 & 95 & 83 \\
\hline
\end{tabular}


The data indicate that a number of economies in transition (ETs) have a fairly high level of development of the $\mathrm{CE}$ and the formed potential for its development. For example, countries such as Belarus, RF, and Ukraine, which have the highest rates of exports of CGs in the ETs, have a rather high value of the GCI. These countries among the top 50 GCI: Belarus (37th), RF (38th), Ukraine (45th), and Montenegro (46th).

The significant potential of ETs is also confirmed by the value of the Global Innovation Index (GII). Part of their follow among the top $50 \mathrm{GII}$ and have maintained relatively stable rankings since 2014: Ukraine (43rd), RF (46th), Moldova (48th). The rest of the countries, except Tajikistan, remain among the 100 GII.

Special attention should be paid to the consideration of the GII in the context of the interdependence of the Input Sub-Index as a set of resources and conditions for innovation and the Output Sub-Index as the results of the implementation of innovations. According to the data presented in the Table 2, most CTEs have significant gaps between their potential and its implementation. In our opinion, this confirms the fact that only the presence of favourable conditions will not be sufficient for the development of CIs in these countries.

We can conclude that CIs, in terms of their share in global GDP, are still in a modest position, in both advanced and DECs and CTEs. At the moment, their economic importance is not as significant as the value of the industrial and resource-saving sectors. However, on the basis of their advantages, systematized in Figure 3, their development will allow the transition from industrial and commodity economies to creative ones, which is especially important for DECs and ETs.

A research revealed that that formation of the concept of "CIs" in ETs is necessary in the context of consideration as an object of state policy and the basis for developing programs to support the development of a CE. Having a clear definition forms the systemic basis for policy development in the field of CIs, which allows the industry to thrive and promote growth, employment and development.

The results of the study revealed that the formation of the concept of "CIs" is closely related to the term "CE" used to describe economic systems, where the value is not determined by traditional resources such as land or capital but depends on originality, creativity (Howkins, 2001). UNCTAD's concept on the Creative Economy is: "< ..> the interface between creativity, culture, economics and technology in a contemporary world dominated by images, sounds, texts and symbols. At the heart of the creative economy are the creative industries" (UNCTAD, 2018).

Based on this, a holistic understanding of CIs is possible only with all aspects of the interaction of creativity, culture, economics, intellectual property and technology. At the same time, depending on the peculiarities of understanding this interaction, differences in the cultural, economic and technological development of countries, different definitions of CIs are formed both in the program documents of international organizations (UNESCO, UNCTAD) and in the program documents of countries.

When forming the national concept of CIs, it is advisable to use the accumulated international experience in this field. The most common definition of "CIs" at an international level is the definition of the Department for Digital, Culture, Media and Sport in the UK: CIs are those "which have their origin in individual creativity, skill and talent and which have a 


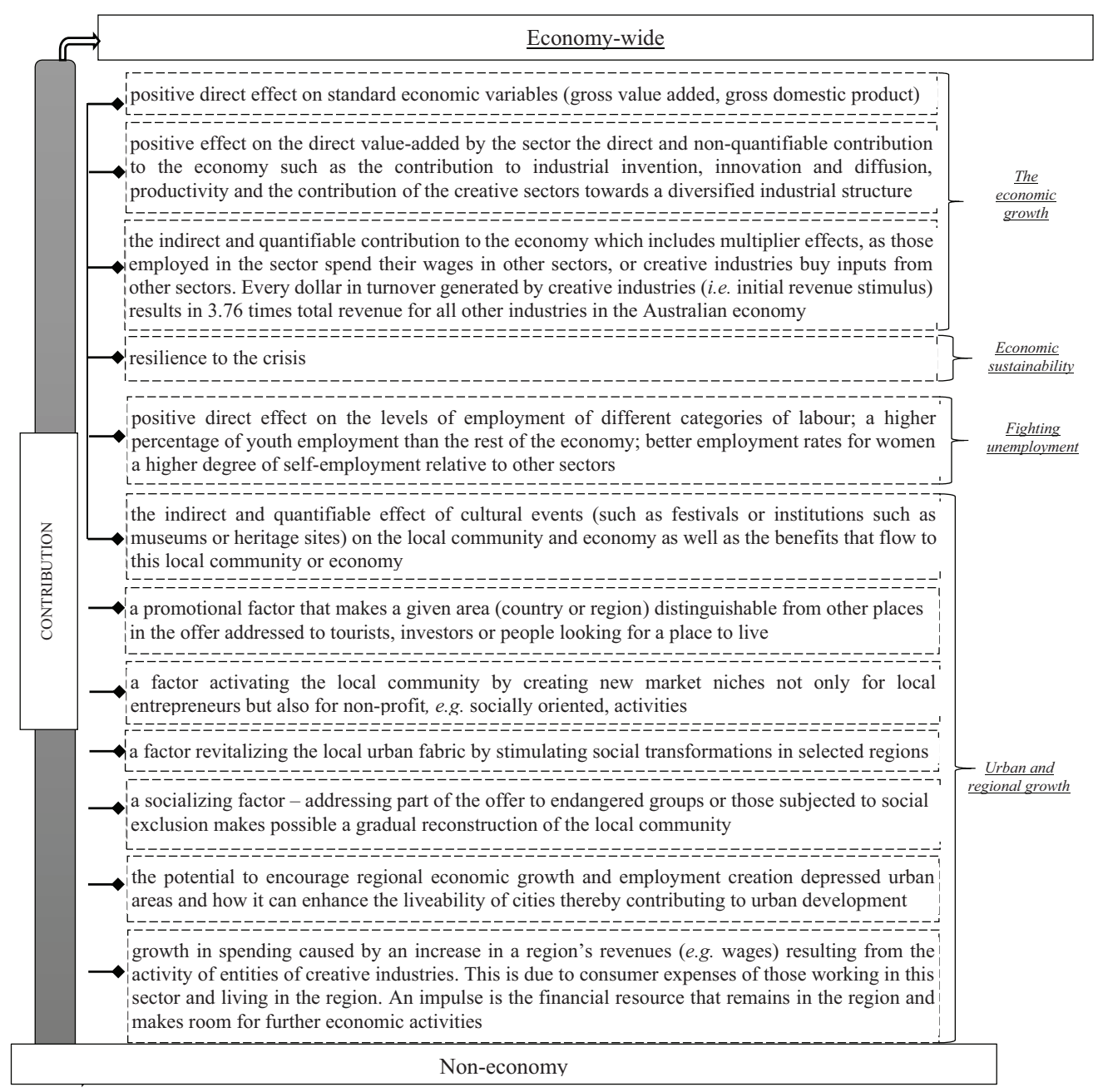

Figure 3. The benefits of creative industries (source: created by authors)

potential for wealth and job creation through the generation and exploitation of intellectual property" (2016, p. 3).

UNESCO approach defines CIs as "sectors of organised activity whose principal purpose is the production or reproduction, promotion, distribution and/or commercialisation of goods, services and activities of a cultural, artistic or heritage-related nature" $(2012,2017)$.

Another common term used to describe the sector is the copyright industries, which lies at the heart of the definition used by World Intellectual Property Organization. The copyright-based industries are defined as those industries in which copyright plays an identifiable role in creating tradable private economic (property) rights and income from the use of these economic rights.

The UK model was introduced in South-East Europe countries during 2005-2006 by the British Council regional project UK South East European Creative Industries Strand. This 
project was dedicated to the promotion of the concept of CIs including in such countries in transition as Serbia, Montenegro, BaH. The project aimed to share the UK experience and knowledge in this field. Several mapping studies were conducted, such as the first national CIs mapping study in Serbia (2006), Albania (2007), Macedonia (2009).

There is no systematic approach to the definition of CIs in most post-Soviet countries, with the exception of Georgia. Ukraine has defined the definition of CIs, but without structuring them.

Thus for ETs, it is necessary to determine their own understanding of CIs with the following main next characteristics of should be taken into account (Țițan, Voineagu, \& Todose, 2008; Butaud-Stubbs \& Konstantinou, 2015):

- at the heart of the activity is the creativity and using of knowledge;

- the production of specific goods and services for local audiences and consumption associated with national cultural identity but competing with international products often protected by intellectual property (copyright and related rights), often short-lived, a high-risk level of failures and unpredictable nature of the use value of products;

- the triple nature: economic (wealth and job creation), cultural (creating values, meaning and identity) and social (creating a major and attractive communication tool);

- a sector where there is no standardised system for paying for the work performed and the prevalence of micro-enterprises, self-employed workers and self-starters;

- the market is highly volatile, depending on fashion, trends and consumption uncertainties.

A classification of CIs is based on different approaches (employment-based concept, industry-based concept), and on various existing pragmatic classifications (International Standard Industrial Classification (ISIC), Central Product Classification and International Standard Classification of Occupations (ISCO).

For define the CIs use the method by which particular job occupations and/or job sectors were determined to be included within the broad concept of the CIs that collectively make up a "CE". A set of five criteria are employed to ascertain that an occupation is creative: novel process, mechanization resistant, a non-repetitive or non-uniform function, a creative contribution to the value chain, and involves interpretation not merely a transformation in the service or artifact (Bakhshi, Freeman, \& Higgs, 2013).

If the profession meets four criteria, then it can be attributed to the group of creative (value 1 assigned where the occupation complies with the criterion and 0 where it does not). Creative intensity calculates by using the creative occupations identified above to determine the proportion of creatively occupied jobs within each industry of employment. A threshold for CIs was determined based on the mean and standard deviation to determine which industries would be classified as creative (creative intensity of $30 \%$ ).

Job occupations and/or job sectors that belong to the creative group and are most common: actors, architects, except landscape, art directors, choreographers, commercial and industrial designers, craft artists, fashion designers, fine artists, graphic designers, interior designers, landscape architects, multi-media artists and animators, music directors and composers, producers and directors, set and exhibit designers, writers and authors.

The industry-based concept it is advisable to base on the international experience of mapping CIs reflected in Figure 4. 


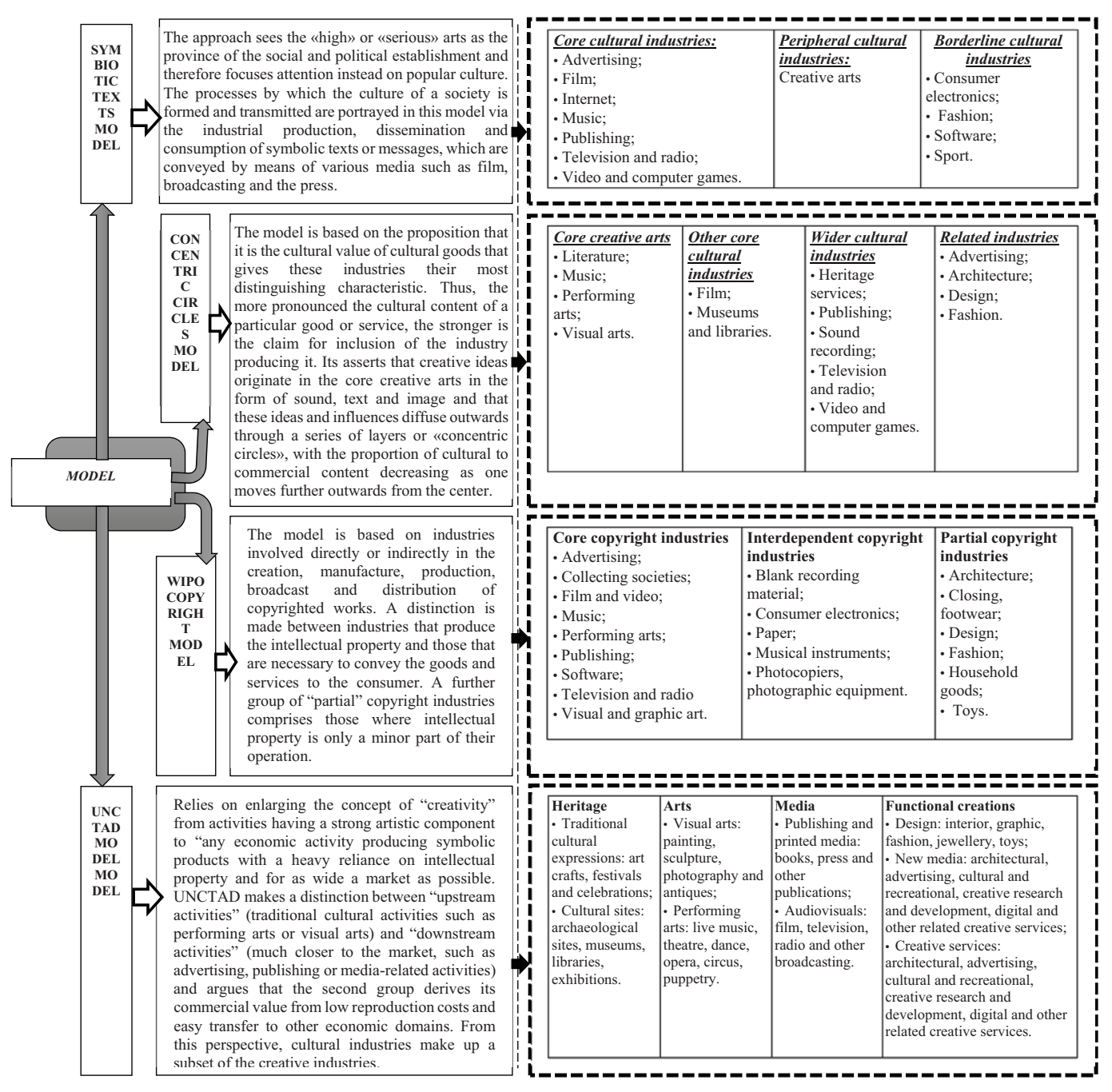

Figure 4. Classification systems for the creative industries from different models (source: created by authors)

Based on them, each country individually forms the composition of industries related to CIs (Table 3).

As we can see, industry categories that are the most common are: advertising; architecture; culture and heritage, including libraries; design; film, video and sound; publishing; music production, distribution and sales; performing arts; publishing; television and radio.

The productions chain model and the classification of CIs in the CTEs cover a small number of activities at a low level of aggregation and very often are the focus on core CUIs (e.g. publishing, film industry, music industry, radio and television). 
Table 3. Comparison of countries: definitions of the creative/cultural industries (source: created by authors)

\begin{tabular}{|c|c|c|c|c|c|c|c|}
\hline \multirow[b]{2}{*}{ Term Used } & $\begin{array}{l}\text { United } \\
\text { Kingdom }\end{array}$ & Germany & France & Poland & Macedonia & Serbia & Georgia \\
\hline & $\begin{array}{l}\text { Creative } \\
\text { industries }\end{array}$ & $\begin{array}{c}\text { Culture \& } \\
\text { creative } \\
\text { industries }\end{array}$ & $\begin{array}{l}\text { Cultural } \\
\text { sector }\end{array}$ & $\begin{array}{l}\text { Creative } \\
\text { industries }\end{array}$ & $\begin{array}{l}\text { Creative } \\
\text { industries }\end{array}$ & $\begin{array}{l}\text { Creative } \\
\text { industries }\end{array}$ & $\begin{array}{l}\text { Cultural } \\
\text { and } \\
\text { creative } \\
\text { industries }\end{array}$ \\
\hline Architecture & $x$ & $x$ & $x$ & $x$ & $x$ & $x$ & $x$ \\
\hline Film and video & $x$ & $x$ & $x$ & $x$ & $x$ & $x$ & $x$ \\
\hline Archives & & & & & $x$ & & \\
\hline Advertising & $x$ & $x$ & & $x$ & $x$ & $x$ & $x$ \\
\hline $\begin{array}{l}\text { Amusement } \\
\text { services }\end{array}$ & & & & & $x$ & & \\
\hline $\begin{array}{l}\text { Art market/ } \\
\text { visual arts }\end{array}$ & $x$ & $x$ & $x$ & $x$ & $x$ & & $x$ \\
\hline $\begin{array}{l}\text { Audio-visual } \\
\text { (television, } \\
\text { radio) }\end{array}$ & $x$ & $x$ & $x$ & $x$ & $x$ & $x$ & $x$ \\
\hline Crafts & $x$ & & & & $x$ & & $x$ \\
\hline Design & $x$ & $x$ & & $x$ & $x$ & $x$ & $x$ \\
\hline Fashion & $x$ & & & $x$ & $x$ & & $x$ \\
\hline Libraries & & & $x$ & $x$ & $x$ & & \\
\hline Museums & & & $x$ & $x$ & $x$ & & $x$ \\
\hline $\begin{array}{l}\text { Cultural } \\
\text { heritage }\end{array}$ & & & & & $x$ & & \\
\hline Music & $x$ & $x$ & $x$ & $x$ & $x$ & $x$ & $x$ \\
\hline Performing arts & $x$ & $x$ & $x$ & $x$ & $x$ & $x$ & $x$ \\
\hline Publishing & $\times$ & $\times$ & $\times$ & $x$ & $\times$ & $\times$ & $\times$ \\
\hline $\begin{array}{l}\text { Software, } \\
\text { computer games } \\
\text { and interactive } \\
\text { media }\end{array}$ & $x$ & $x$ & & $x$ & $x$ & $x$ & $x$ \\
\hline $\begin{array}{l}\text { Education, } \\
\text { training, } \\
\text { consulting }\end{array}$ & & & & & $\begin{array}{c}\text { Only } \\
\text { foreign } \\
\text { language } \\
\text { school }\end{array}$ & & \\
\hline $\begin{array}{l}\text { Cultural- } \\
\text { training } \\
\text { activities }\end{array}$ & & & & & $x$ & & \\
\hline
\end{tabular}

At the same time, wanted to emphasize that the cultural and creative expression is different for each country. Based on this, it is advisable to consider alternative creative activities (CAs) in each of the CTEs if they demonstrate high potentials, e.g. gastronomy, winemaking, cultural tourism or crafts (BOP Consulting, 2010). 
After forming a clear understanding of CIs and their structuring for the formation of a policy of their development it is necessary to conduct a comprehensive analysis. Analysis of CCIs must be formed a clear understanding of the specific characteristics of the CCIs in the country/region: their strengths, weaknesses, key enablers and overall development trends (Figure 5).

As the data presented in Figure 5 shows, a significant number of factors affect the development of CIs. It should be emphasized that some of them are of a general nature and form the operating environment of the activities of creative enterprises, which is almost impossible to change in the short-term time horizon. These factors, in particular, include the economic development of the country as a whole and the standard of living of the population in particular.

For the development of CIs, a middle class in the country must be sufficiently numerous to provide both a steady demand for the products of CIs and to exercise "control" over manufacturers, placing high demands on their products and contributing to the constant

Formation of the definition of creative industries

Structuring of creative industries and the identifying the full matrix of sub-sectors, businesses and workers that make up this sector

Analysis of the external environment impact on the state and prospects of the development of creative industries

\begin{tabular}{|c|c|c|c|c|c|c|c|}
\hline \multicolumn{8}{|c|}{ Formation of a system of factors related to the characteristics of political, economic and social environments } \\
\hline $\begin{array}{l}\text { Global } \\
\text { macroeconomic } \\
\text { conditions, } \\
\text { including } \\
\text { dependence on } \\
\text { the world } \\
\text { economy and } \\
\text { terms of trade }\end{array}$ & $\begin{array}{c}\text { Internal } \\
\text { macroeconomic } \\
\text { conditions, } \\
\text { including state } \\
\text { budget, balance } \\
\text { of payments and } \\
\text { real sector }\end{array}$ & $\begin{array}{c}\text { Institutional (openness } \\
\text { of economy, level of } \\
\text { control over markets, } \\
\text { degree of financial } \\
\text { liberalization, } \\
\text { frequency and depth } \\
\text { of previous crises) }\end{array}$ & $\begin{array}{l}\text { Political (effectiveness of } \\
\text { state management of the } \\
\text { economy, political risks, } \\
\text { quality of the legislative } \\
\text { base; the index of political } \\
\text { stability, the index of } \\
\text { Regulatory Quality, Index } \\
\text { of State Weakness) }\end{array}$ & $\begin{array}{l}\text { The nature of } \\
\text { consumers, } \\
\text { which is the } \\
\text { product of } \\
\text { creative } \\
\text { industries }\end{array}$ & $\begin{array}{l}\text { Specific requirements } \\
\text { for the quality of labour } \\
\text { resources in terms of the } \\
\text { ability to creative } \\
\text { thinking, the generation } \\
\text { of new ideas, original } \\
\text { solutions, the ability to } \\
\text { master new technologies }\end{array}$ & $\begin{array}{c}\text { Access to } \\
\text { finance and } \\
\text { an } \\
\text { extensive } \\
\text { financial } \\
\text { system }\end{array}$ & $\begin{array}{c}\text { Presence of } \\
\text { institutional } \\
\text { framework } \\
\text { and } \\
\text { developed } \\
\text { infrastructure }\end{array}$ \\
\hline
\end{tabular}

\begin{tabular}{|c|c|c|c|c|}
\hline $\begin{array}{l}\text { Expert assessment of } \\
\text { the impact on the } \\
\text { creative industry with } \\
\text { the division into } \\
\text { opportunities and } \\
\text { threats }\end{array}$ & $\begin{array}{l}\text { Selection of key } \\
\text { external factors } \\
\text { (TEMPLES } \\
\text { analysis and } \\
\text { SWOT analysis) }\end{array}$ & Opportunities & $\begin{array}{l}\text { Formation of an } \\
\text { external macro } \\
\text { profile }\end{array}$ & $\begin{array}{l}\text { Formation of indicators that determine the most } \\
\text { significant external factors in terms of } \\
\text { implementation of threats and opportunities for } \\
\text { the development of creative industries }\end{array}$ \\
\hline \multicolumn{2}{|c|}{$\begin{array}{l}\text { Formation of short - and medium - } \\
\text { term forecasts of the development of } \\
\text { the environment }\end{array}$} & \multicolumn{3}{|c|}{$\begin{array}{c}\text { Forecasting indicators that determine the most significant external factors of influence in } \\
\text { terms of the implementation of threats and the use of opportunities for the development } \\
\text { of creative industries }\end{array}$} \\
\hline \multicolumn{5}{|c|}{$\begin{array}{l}\text { Analysis of the status of creative industries, taking into account the state of the external macro environment: } \\
\text { - identifying the magnitude and characteristics of the creative economy; } \\
\text { - measuring the value and impact of the CCI and creative economy, inventory and measure its economic and non-economic contribution; } \\
\text { - measuring the return on investment in this economic cluster over time; } \\
\text { - setting a baseline for development goals in public police; } \\
\text { - visual mapping (maps of cultural and creative entities) is a source for clustering initiatives, as well as a potential tool for urban planning. }\end{array}$} \\
\hline
\end{tabular}

Figure 5. Directions of analysis in the context of developing a state policy for the development of creative industries (source: created by authors) 
improvement of their quality and maintaining competition in the industry. At the same time, living standards and incomes in CTEs are low. Therefore, for the development of CIs, first of all, structural reforms are needed that will improve the standard of living in the country.

Based on this, we believe that the subjects of state regulation responsible for the development of public policy should choose from the entire spectrum of factors those that can be changed using the tools at their disposal with minimal expenditure of resources and time. Factors determining the consumption of cultural services (i.e. products of the CI) are not limited to a household's financial status, but also include level of education, the level of the cultural education of its members, their actual and expected social status, leisure resources, etc. In addition, those other factors make the demand for products of the creative sector (CS) highly unpredictable.

Based on the results of studying, the key factors, determining CCIs development, were structured into the following groups (Kloudova, 2010; Newbigin, 2010; Kasprzak, 2013; Liu \& Chiu, 2017):

- quality of strategic political tools for the sector. On different level, these tools might take different forms, including regional strategies, local development plans and national policy papers. Overall, two main options are often used. Firstly, establishing a separate CCIs policy or strategy, and secondly, integrating CCIs into many other key policies and strategies education of members of the CS: most universities (schools) educating workers in this sector do not prepare them for economic activity, focusing on the transfer of knowledge from a specific discipline of art;

- quality of the institutional framework (Delibasic, 2016; Draskovic, Popov, \& Peleckis, 2017). When shaping the institutional support for the development of CIs in ETs, it is necessary to use the European models for creating intersectoral and interdepartmental working groups at the local, regional, national and international levels. The target group for these activities is the policymakers, cultural operators, creative entrepreneurs, other industries as well as the public. As an example, Georgia initiated the establishment of the Intergovernmental Commission for Developing Creative Industries (ICDCI) in March 2016. Comprising the representatives of different state agencies, such as the Ministry of Finance of Georgia, the Ministry of Education and Science of Georgia, the Ministry of Economy and Sustainable Development of Georgia, the Ministry of Sport and Youth Affairs of Georgia, the Tbilisi City Hall and Tbilisi City Assembly, Enterprise Georgia and the Georgia's Innovation and Technology Agency, the aim of the ICDCI is to mobilise all available resources at relevant governmental agencies in order to implement (joint) projects;

- quality of staffing of the CIs (training and staff development in the system of formal and non-formal education, the presence of a model of competence and authority). A true "knowledge economy" depends on the ability of the workforce to think creatively and flexibly, not just for the CS but for the economy. Seen from this perspective, higher education institutions are no longer external to the economy, but an integral part of it. All activities should be directed to the competence of members of the CS, the formation of skills in areas necessary for economic activity, such as legal and tax issues, the ability to acquire funds (not only public), as well as the ability to plan the development of the organization;

- quality of infrastructure and communications at local, regional and national levels contribute to the emergence of creative communities. Infrastructure may be defined 
as physical or virtual assets and spaces, whether full-time or part-time, single purpose or multipurpose, historic or contemporary - that support CPs and activities, and that accommodate and satisfy the requirements of activities and CIs. Communications in stimulating the development of CIs is a continuous process that is needed at both the initial stage of developing policies and strategies, and in developing partnerships in CIs and other sectors. Awareness-raising initiatives pursue different goals, including encouraging creative people (CPE) to start a business, expanding cooperation between creative entrepreneurs, training both entrepreneurs and consumers, combining creative industries with traditional industries, etc.;

- availability of access to permanent sources of funding (both for loans and capital) for $\mathrm{CPE}$ and enterprises, ensuring the creation and development of CAs, an effective system of tax incentives and taxation.

Based on the results obtained, the key triggers that should be influenced by government regulation in CTEs in the initial stages of stimulating the development of CIs, are: ensuring access to finance, ensuring an effective system of education at all levels to ensure the availability of skilled labour and literacy consumers of CPs, availability of high-quality infrastructure and regulatory system.

Proceeding from this, recommendations for the development of CI in the ETs structured in terms of the key factors and stakeholders. The main actions of state regulatory bodies are given in Table 4.

Table 4. Key actions for the development of creative industries in economies in transition (source: created by authors (based on Creative Industries Council, 2018; Working Group of EU Member States Experts (Open Method of Coordination) on Cultural and Creative Industries, 2012; Bedianashvili, 2016)

\begin{tabular}{|c|c|c|c|}
\hline & Government & Local government & Best practics: United Kingdom \\
\hline 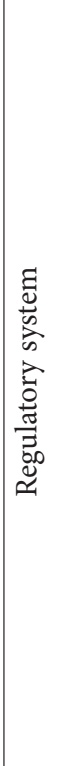 & $\begin{array}{l}\text { 1) Integration of a creative } \\
\text { economy into the state policy } \\
\text { and policy development for } \\
\text { the creative industries sector. } \\
\text { 2) Development of public } \\
\text { policy and regulatory } \\
\text { framework for the protection } \\
\text { of intellectual property and } \\
\text { competition. } \\
\text { 3) Formation of the } \\
\text { institutional structure } \\
\text { responsible for the } \\
\text { development of creative } \\
\text { industries. }\end{array}$ & $\begin{array}{l}\text { Elaborating local } \\
\text { strategies and programs } \\
\text { for the promotion of the } \\
\text { development of cultural } \\
\text { and creative industries. } \\
\text { The documents should be } \\
\text { integrated into regional } \\
\text { development strategies, } \\
\text { targeted toward regional } \\
\text { or urban development and } \\
\text { support their uniqueness } \\
\text { and business development. }\end{array}$ & $\begin{array}{l}\text { 1) The Creative Industries } \\
\text { Council was created, responsible } \\
\text { for identifying obstacles to the } \\
\text { development of creative industries } \\
\text { and the development of measures } \\
\text { to eliminate them. Creative } \\
\text { Industries Council members are } \\
\text { leading figureheads drawn from } \\
\text { across the creative and digital } \\
\text { industries including television, } \\
\text { computer games, fashion, music, } \\
\text { arts, publishing and film. } \\
\text { 2) Development of strategies } \\
\text { for the development of creative } \\
\text { industries is carried out on an } \\
\text { ongoing basis with monitoring } \\
\text { their implementation and tracking } \\
\text { the dynamics of achievements. In } \\
\text { the current period, the strategy } \\
\text { "Create Together" has been } \\
\text { developed, to be implemented in } \\
\text { the next five years. }\end{array}$ \\
\hline
\end{tabular}


Continued Table 4

\begin{tabular}{|c|c|c|c|}
\hline & Government & Local government & Best practics: United Kingdom \\
\hline & $\begin{array}{l}\text { 1) Financing the training } \\
\text { of labor resources at the } \\
\text { expense of state institutions. } \\
\text { 2) Talent training financed by } \\
\text { the government. } \\
\text { 3) Government scholarships } \\
\text { for studying abroad. } \\
\text { 4) Providing industrial } \\
\text { consulting, counselling } \\
\text { and support regarding } \\
\text { commercialization agreement } \\
\text { on intellectual property, } \\
\text { the corporate operation of } \\
\text { creativity firms, and the } \\
\text { incubation. }\end{array}$ & $\begin{array}{l}\text { 1) Financing of human } \\
\text { resources training at the } \\
\text { expense of local budgets. } \\
\text { 2) Scholarship support for } \\
\text { talented young people. } \\
\text { 3) Provision of industrial } \\
\text { consulting, consulting and } \\
\text { support in relation to the } \\
\text { commercial agreement } \\
\text { on intellectual property, } \\
\text { corporate activities of } \\
\text { creativity and incubation } \\
\text { firms. }\end{array}$ & $\begin{array}{l}\text { Great attention is paid to } \\
\text { educational programs and } \\
\text { methodological recommendations } \\
\text { on creating your own business, } \\
\text { the tax system, tools for obtaining } \\
\text { financing and much more. At the } \\
\text { moment, Government Training } \\
\text { Programs include: E-learning for } \\
\text { small businesses; HM Revenue } \\
\text { and Customs Webinars covering } \\
\text { subjects such as business } \\
\text { expenses, value-added tax and } \\
\text { capital allowances. }\end{array}$ \\
\hline 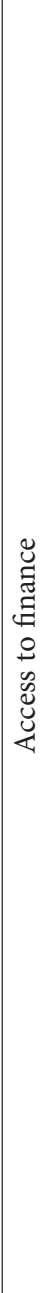 & $\begin{array}{l}\text { 1) Introduction of tax } \\
\text { incentives. 2) Participation } \\
\text { in the co-financing of } \\
\text { enterprises of the cultural } \\
\text { and creative industries } \\
\text { of national importance. } \\
\text { 3) Development of a } \\
\text { mechanism for public-private } \\
\text { partnerships to establish } \\
\text { financing mechanisms, as } \\
\text { well as the realization of } \\
\text { projects. } \\
\text { 4) Development of } \\
\text { preferential crediting } \\
\text { mechanisms in conjunction } \\
\text { with state banks. } \\
\text { 5) Developing financial } \\
\text { programs for small and } \\
\text { medium-sized enterprises. } \\
\text { 6) Stimulating private } \\
\text { investment and promoting } \\
\text { public-private partnerships } \\
\text { for the benefit of their } \\
\text { cultural and creative } \\
\text { industries small and } \\
\text { medium-sized enterprises, } \\
\text { notably through guarantee } \\
\text { mechanisms or venture } \\
\text { capital funds. } \\
\text { 7) Support for artists and } \\
\text { the arts, both direct (via } \\
\text { fiscal means) and indirect } \\
\text { (through encouragement } \\
\text { of private sector support). } \\
\text { 8) Development of a } \\
\text { mechanism for the work of } \\
\text { incubators and accelerators. }\end{array}$ & $\begin{array}{l}\text { 1) Formation of regional } \\
\text { budgets supporting the } \\
\text { development of cultural } \\
\text { and creative industries. } \\
\text { 2) Funding cultural } \\
\text { events and cultural places } \\
\text { of regional and local } \\
\text { importance. } \\
\text { 3) Co-financing business } \\
\text { incubators and accelerators. }\end{array}$ & $\begin{array}{l}\text { Existence of an extensive } \\
\text { financing system: the creation } \\
\text { of agencies, the provision of } \\
\text { premises on concessional terms, } \\
\text { grants and affordable loans, the } \\
\text { distribution of business angels } \\
\text { (private investors who invest } \\
\text { their own funds in unusual and } \\
\text { promising projects at the stage of } \\
\text { creating a company in exchange } \\
\text { for a share in its capital) to the } \\
\text { creative entrepreneurship. In } 2018 \\
\text { the government and the creative } \\
\text { industries sector, through the } \\
\text { Creative Industries Council, have } \\
\text { agreed a Sector Deal, which will } \\
\text { invest more than } £ 150 \text { million } \\
\text { across the lifecycle of creative } \\
\text { businesses, including: places of } \\
\text { the future - by funding leading } \\
\text { creative clusters to compete } \\
\text { globally; technologies and content } \\
\text { of the future - via research into } \\
\text { augmented reality and virtual } \\
\text { reality; creative skills of the } \\
\text { future - via a careers programme } \\
\text { that will open up creative jobs to } \\
\text { people of every background. }\end{array}$ \\
\hline
\end{tabular}


End of Table 4

\begin{tabular}{|c|c|c|c|}
\hline & Government & Local government & Best practics: United Kingdom \\
\hline 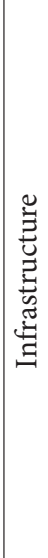 & $\begin{array}{l}\text { 1) Helding cultural activities } \\
\text { and performances by the } \\
\text { government. 2) Management } \\
\text { of cultural and creative } \\
\text { industries parks, Creative } \\
\text { Hubs, cultural and } \\
\text { creative industries clusters, } \\
\text { international networks } \\
\text { and alliances with creative } \\
\text { hubs and entrepreneurs, } \\
\text { cultural facilities, such as } \\
\text { museums and galleries, as } \\
\text { crucial brands of cultural } \\
\text { and creative industries, and } \\
\text { implement effective branding } \\
\text { to promote them. }\end{array}$ & $\begin{array}{l}\text { 1) Elaborating local } \\
\text { strategies and programs } \\
\text { for the promotion of the } \\
\text { development of cultural } \\
\text { and creative industries } \\
\text { integrated into regional } \\
\text { development strategies. } \\
\text { 2) Development of a } \\
\text { complex of activities that } \\
\text { stimulate clustering and } \\
\text { network activities, that } \\
\text { build interaction between } \\
\text { various stakeholders. }\end{array}$ & $\begin{array}{l}\text { 1) The government's proposed } \\
\text { broadband investment fund } \\
\text { to support alternative network } \\
\text { developers should give creative } \\
\text { clusters a key role. This fund } \\
\text { should be structured as a } \\
\text { demonstrator so that all clusters } \\
\text { can benefit from insights into } \\
\text { how they can best support local } \\
\text { creative businesses. }\end{array}$ \\
\hline
\end{tabular}

Enterprises of the creative sector to ensure their effective functioning should:

- in infrastructure - to have taken an active part in CCIs parks, creative hubs, CCIs clusters, networks and alliances; to have unite all interested parties for the development of CCIs; to have share best practices and examples of the effective implementation of creative projects; to have publication and dissemination of information on local and international trends and events in CIs; to have disseminate information on examples of successful cooperation between the business sector and cultural organizations;

- in the field of education - to have develop corporate training.

The important role in the development of CIs in the whole world is assigned to higher educational institutions. This is due to the fact that the intellectual potential of both producers and consumers CGs is of key importance in the development of the CS. Therefore, higher education institutions should be an active participant in all processes related to the development and implementation of a strategy for the development of a CE in the country, be an integral element of its infrastructure. The main activities of higher education institutions in this area are described below:

- in the field of education - to have develop of study programs, aimed at training specialists in sectors related to CIs, and professional programs for specialists in CIs; to have develop of entrepreneurship skills among the students; to have develop of targeted educational initiatives for creation of new jobs and promotion of sustainable career of students and graduates;

- in infrastructure - take an active part in the formation of the regional infrastructure of functioning of CIs and actively attract students to work in them; to participate in the creation of creative incubators and hubs and the development of new business models of these institutions;

- provide access to finance, creating and ensuring the effective use of funds for the implementation of student projects in the field of CAs. 


\section{Conclusions}

The authors studied the concept of the CI in the context of international and national practice.

1. From the study, we can conclude that CIs, in terms of their share in global GDP, are still in a modest position, in both advanced and DECs and CTEs. At the moment, their economic importance is not as significant as the value of the industrial and resource-saving sectors. However, on the basis of their advantages (value-added growth, new job creation, regional development) their improvement will allow the transition from industrial and commodity economies to creative ones, which is especially important for DECs and CTEs.

2. The authors determined that for the formation of a policy of development of CCIs it is necessary to conduct a comprehensive analysis, which must be formed a classification of CIs, clear understanding of the specific characteristics of the CCIs in the country/region: their strengths, weaknesses, key enablers and overall development trends.

3. Authors determined that the classification of CIs is based on different approaches (concept based on employment, industry concept) and on various existing pragmatic classifications (ISIC, classification of main products and ISCO). At the same time, it was determined that when developing a system for structuring CIs, it is necessary to consider not only the approaches developed by international practice, but also national peculiarities.

4. The study found that the development of CIs, first of all, depends on the general business climate in the country and the standard of living of the population as the main consumer of CGs and services. This is what forms the basis for the emergence of a creative class and increased demand for the products of this sector. As Farinha (2018b) notes, as before, in most CTEs, culture is considered a luxury and is regarded as an industry with low productivity, in which resources are almost not needed. These factors, in our opinion, have a significant negative impact on the development of CIs in the countries studied.

5. The authors have determined that despite the systemic nature of the most factors affecting the development of CIs, there is a sufficiently large list of obstacles to the development of CIs, which can be eliminated even in conditions of limited resources, which, in turn, can serve as an impetus for the further development of the sector in CTEs.

6. Based on the results of studying, the key factors, stimulating CCIs development, is: quality of strategic political tools for the sector; quality of the institutional framework; quality of staffing of the CIs; quality of infrastructure and communications at local, regional and national levels; availability of access to permanent sources of funding (both for loans and capital) for CPE and enterprises, ensuring the creation and development of CAs, an effective system of tax incentives and taxation. Separating the factors that hinder the development of CIs at the moment and in the future, the subjects of state regulation will be able to form a set of measures to eliminate them, which will make the most of the economic and social potential of CA.

7. Based on this approach, the recommendations for the development of CIs in CTEs are structured in terms of key influencing factors (regulatory system, education, access to finance, infrastructure) and key stakeholders: government, local authorities (regions and cities), higher education institutions, the CI and other business representatives. 


\section{References}

Analiticheskiy tsentr pri pravitelstve Rossiyskoy federatsii. (2017). Obrazovanie i kreativnaja industrija v zerkale mezhdunarodnyh i otechestvennyh praktik. Bjulleten' o sfere obrazovanija 13. Retrieved from http://ac.gov.ru/files/publication/a/14525.pdf

Anatoliivna Vasylieva, T., \& Kas'yanenko, V. O. (2013). Integral'ne ocinjuvannja innovacijnogo potencialu nacional'noï ekonomiki Ukraïni: naukovo-metodichnij pidhid i praktichni rozrahunki. Aktual'ni problemi ekonomiki, 6(144), 50-59.

Bakhshi, H., Freeman, A., \& Higgs, P. (2013). A dynamic mapping of the UK's creative industries. Retrieved from https://eprints.qut.edu.au/57251/1/57251.pdf

Balcerzak, P. A., \& Pietrzak, B. M. (2017). Digital economy in Visegrad countries. Multiple-Criteria decision analysis at regional level in the years 2012 and 2015. Journal of Competitiveness, 9(2), 5-18. https://doi.org/10.7441/joc.2017.02.01

Bedianashvili, G. (2016). 22 recommendations for development of creative industry in Georgia. Culture \& Creativity. Retrieved from https://www.culturepartnership.eu/en/article/recommendationsof-representatives-of-creative-industry

Beukelaer, De Ch. (2014). Creative industries in “developing” countries: Questioning country classifications in the UNCTAD creative economy reports. Cultural Trends, 23(4), 232-251.

https://doi.org/10.1080/09548963.2014.912043

Beukelaer, De Ch., \& Koretskaya, G. (2016). Cultural industries in Kazakhstan: Models, challenges, and strategies. Almaty: British Council Kazahstan.

Boix, R., Lazzeretti, L., Capone, F., Propris, de L., \& Sánchez, D. (2013). The geography of creative industries in Europe: Comparing France, Great Britain, Italy and Spain. In L. Lazzeretti (Ed.), Creative industries and innovation in Europe: Concepts, measures and comparative case studies. Series: Regions and Cities. New York: Routledge (pp. 23-44).

Bontje, M., \& Musterd, S. (2009). Creative industries, creative class and competitiveness: Expert Opinions critically appraised. Geoforum, 40(5), 843-852. https://doi.org/10.1016/j.geoforum.2009.07.001

BOP Consulting. (2010). Mapping the creative industries: A toolkit. Series: Creative and Cultural Economy Series. Vol. 2. Retrieved from https://creativeconomy.britishcouncil.org/media/uploads/files/ English_mapping_the_creative_industries_a_toolkit_2-2.pdf

Bubenko, P. T., \& Luk'yanets', S. P. (2014). Komercializacija ob'€ktiv intelektual'noï dijal'nosti ta ïh rol' u rozvitku kreativnih industrij. Ekonomichnij forum, 4, 70-77.

Butaud-Stubbs, E., \& Konstantinou, N. (2015). Creative and cultural industries - A European asset to be used in global competition (own-initiative opinion). Retrieved from https://www.eesc.europa.eu/en/ our-work/opinions-information-reports/opinions/creative-and-cultural-industries-european-assetbe-used-global-competition-own-initiative-opinion

Comunian, R., Chapain, C., \& Clifton, N. (2010). Location, location, location: Exploring the complex relationship between creative industries and place. Creative Industries Journal, 3(1), 5-10. https://doi.org/10.1386/cij.3.1.5_2

Cooke, Ph., \& Lazzeretti, L. (Eds.). (2008). Creative cities, cultural clusters and local economic development. Series: New Horizons in Regional Science. Ph. McCann (Series Ed.). Cheltenham, Northampton, MA: Edward Elgar.

Creative Industries Council. (2018). Create together. A creative industries council strategy for cross industry collaboration: The next 5 years. Retrieved from http://www.thecreativeindustries.co.uk/media/367095/final-version-july-5.pdf

Cunningham, S. D. (2002). From cultural to creative industries: Theory, industry and policy implications. Media International Australia Incorporating Culture and Policy: Quarterly Journal of Media Research and Resources, 102(1), 54-65. https://doi.org/10.1177/1329878X0210200107 
Daubaraite, U., \& Startienė, G. (2015). Creative industries impact on national economy in regard to sub-sectors. Procedia - Social and Behavioral Sciences, 213, 129-134.

https://doi.org/10.1016/j.sbspro.2015.11.415

Delibasic, M. (2016). Hypothetical matrix for institutional modeling of the basis for economic development in the countries of Southeast Europe. Montenegrin Journal of Economics, 12(2), 147-159. https://doi.org/10.14254/1800-5845/2016.12-2.9

Draskovic, V., Popov, E., \& Peleckis, K. K. (2017). Modelling of institutional changes in transition countries - the gap between the theory and practice. Montenegrin Journal of Economics, 13(1), 125-140. https://doi.org/10.14254/1800-5845/2017.13-1.9

Dutta, S., Lanvin, B., \& Wunsch-Vincent, S. (Eds.). (2018). Global Innovation Index 2018: Energizing the world with innovation. Geneva and New Delhi: World Intellectual Property Organization, Confederation of Indian Industry.

Evans, G. (2009). Creative cities, creative spaces and urban policy. Urban Studies, 46(5-6), 1003-1040. https://doi.org/10.1177/0042098009103853

ey.com. (2014). Creating growth: Measuring cultural and creative markets in the EU. Retrieved from https://www.ey.com/Publication/vwLUAssets/Measuring_cultural_and_creative_markets_in_the_ EU/\$FILE/Creating-Growth.pdf

ey.com. (2015). Cultural times: The first global map of cultural and creative industries. Retrieved from https://www.ey.com/Publication/vwLUAssets/ey-cultural-times-2015/\$FILE/ey-culturaltimes-2015.pdf

Farinha, C. (2018a). Developing cultural and creative industries in Armenia. Retrieved from http://www. culturepartnership.eu/upload/editor/2017/Policy\%20Briefs/171221\%20Creative\%20Industries\%20 Report\%20for\%20Armenia.pdf

Farinha, C. (2018b). Developing cultural and creative industries in Azerbaijan. Retrieved from http:// www.culturepartnership.eu/upload/editor/2017/Policy\%20Briefs/180315\%20Creative\%20Industries\%20Report\%20for\%20Azerbaijan.pdf

Farinha, C. (2018c). Developing cultural and creative industries in Belarus. Retrieved from https://www. culturepartnership.eu/upload/editor/2017/Policy\%20Briefs/180115\%20Creative\%20Industries\%20 Report\%20for\%20Belarus.pdf

Farinha, C. (2018d). Developing cultural and creative industries in Georgia. Retrieved from https:// www.culturepartnership.eu/upload/editor/2017/Research/171116\%20Creative\%20Industries\%20 Report\%20for\%20Georgia.pdf

Farinha, C. (2018e). Developing cultural and creative industries in Moldova. Retrieved from http://www. culturepartnership.eu/upload/editor/2017/Policy\%20Briefs/180111\%20Creative\%20Industries\%20 Report\%20for\%20Moldova_upd.pdf

Farinha, C. (2018f). Developing cultural and creative industries in Ukraine. Retrieved from www.culturepartnership.eu/upload/editor/2017/Research/Creative\%20Industries\%20Report $\% 20$ for\%20 Ukraine.pdf

Flew, T. (2005). Creative economy. In J. Hartley (Ed.), Creative industries. Malden, MA: Blackwell Publishing Ltd. (pp. 344-360).

Flew, T. (2012). The creative industries: culture and policy. Los Angeles: SAGE.

Flew, T., \& Cunningham, S. (2010). Creative industries after the first decade of debate. The Information Society: An International Journal, 26(2), 113-123. https://doi.org/10.1080/01972240903562753

Florida, R. (2005a). Cities and the creative class. New York, London: Routledge. https://doi.org/10.4324/9780203997673

Florida, R. (2005b). The flight of the creative class: The new global competition for talent. New York: Harper Business. https://doi.org/10.4324/9780203997673 
Florida, R. (2014). The rise of the creative class, revisited. New York: Basic Books.

Florida, R., Mellander, Ch., \& King, K. (2015). The global creativity index 2015. Toronto: Martin Prosperity Institute.

Foord, J. (2008). Strategies for creative industries: An international review. Creative Industries Journal, 1(2), 91-113. https://doi.org/10.1386/cij.1.2.91_1

Galloway, S., \& Dunlop, S. (2007). A critique of definitions of the cultural and creative industries in public policy. International Journal of Cultural Policy, 13(1), 17-31. https://doi.org/10.1080/10286630701201657

García Lorente, J. (2016). The creative economy: The new El Dorado that Europe and Latin America want to lead. IE University. Retrieved from https://www.ie.edu/insights/articles/the-creative-economy-the-new-dorado-that-europe-and-latin-america-want-to-lead/

Garnham, N. (2005). From cultural to creative industries. International Journal of Cultural Policy, 11(1), 15-29. https://doi.org/10.1080/10286630500067606

Gibson, Ch. R. (2006). Sydney's creative economy: Social and spatial challenges. In R. Freestone, B. Randolph, \& C. Butler-Bowdon (Eds.), Talking about Sydney: Population, community and culture in contemporary Sydney. Sydney: University of New South Wales Press (pp. 185-197).

Godlewska-Majkowska, H., Komor, A., \& Typa, M. (2016). Special economic zones as growth and antigrowth poles as exemplified by Polish regions. Entrepreneurial Business and Economics Review, 4(4), 189-212. https://doi.org/10.15678/EBER.2016.040412

Hall, Sir P. (2000). Creative cities and economic development. Urban Studies, 37(4), 639-649. https://doi.org/10.1080/00420980050003946

Hartley, J. (2005). Creative industries. Malden, MA: Blackwell Publishing Ltd.

Hesmondhalgh, D. (2015). The cultural industries. Los Angeles: SAGE.

Hesmondhalgh, D., \& Pratt, A. C. (2005). Cultural industries and cultural policy. International Journal of Cultural Policy, 11(1), 1-14. https://doi.org/10.1080/10286630500067598

Higgs, P., \& Cunningham, S. (2008). Creative industries mapping: Where have we come from and where are we going? Creative Industries Journal, 1(1), 7-30. https://doi.org/10.1386/cij.1.1.7_1

Higgs, P., Cunningham, S., \& Bakhshi, H. (2008). Beyond the creative industries: Mapping the creative economy in the United Kingdom. Retrieved from https://eprints.qut.edu.au/12166/1/beyond_creative_industries_report_NESTA.pdf

Higgs, P., Cunningham, S., \& Pagan, J. (2007). Australia's creative economy: Definitions of the segments and sectors. Brisbane: ARC Centre of Excellence for Creative Industries and Innovation.

Horkheimer, M., \& Adorno, Th. W. (2009). Dialectic of enlightenment: Philosophical fragments. Stanford, CA: Stanford University Press.

Howkins, J. (2001). The creative economy: How people make money from ideas. London: Penguin.

Kasprzak, R. (2013). Przemysty kreatywne w Polsce: perspektywy i uwarunkowania. Warszawa: Kamon Consulting.

Kholodnitskaya, A. V. (2018). Aktual'ni tendenciyi rozvy'tku kreaty'vny'x industrij v Ukrayini v umovax globalizaciyi. Ekonomika i suspil'stvo, 14, 151-157.

Kloudova, Y. (2010). The impact of the creative economy in the economically backward regions. Journal of the New Economic Association, 5, 110-25.

Krätke, S. (2010). "Creative cities" and the rise of the dealer class: A critique of Richard Florida's approach to urban theory. International Journal of Urban and Regional Research, 34(4), 835-853. https://doi.org/10.1111/j.1468-2427.2010.00939.x

Landry, Ch. (2011). A roadmap for the creative city. In D. E. Andersson, Å. E. Andersson, \& Ch. Mellander (Eds.), Handbook of creative cities. Cheltenham: Edward Elgar Publishing Limited (pp. 517536). https://doi.org/10.4337/9780857936394.00036 
Landry, Ch. (2005). Lineages of the creative city. Retrieved from http://charleslandry.com/panel/wpcontent/uploads/downloads/2013/03/Lineages-of-the-Creative-City.pdf

Landry, Ch. (2008). The creative city: A toolkit for urban innovators. London, Sterling, VA: Earthscan.

Landry, Ch., \& Bianchini, F. (1995). The creative city. London: Demos.

Lazzeretti, L., Capone, F., \& Innocenti, N. (2018). The rise of cultural and creative industries in creative economy research: A bibliometric analysis. In L. Lazzeretti, M. Vecco (Eds.), Creative industries and entrepreneurship: Paradigms in transition from a global perspective. Cheltenham, Northampton, MA: Edward Elgar Publishing (pp. 13-34). https://doi.org/10.4337/9781786435927.00007

Liu, Y.-Y., \& Chiu, Y.-H. (2017). Evaluation of the policy of the creative industry for urban development. Sustainability, 9(6-1009), 1-23. https://doi.org/10.3390/su9061009

Lyeonov, S. V., Vasylieva, T. A., \& Lyulyov, O. V. (2018). Macroeconomic stability evaluation in countries of lower-middle income economies. Scientific Bulletin of National Mining University, 1, 138-146. https://doi.org/10.29202/nvngu/2018-1/4

Madrak-Grochowska, M. (2015). The knowledge-based economy as a stage in the development of the economy. Quarterly Journal Oeconomia Copernicana, 6(2), 7-20.

https://doi.org/10.12775/OeC.2015.009

Markusen, A., Wassall, G. H., DeNatale, D., \& Cohen, R. (2008). Defining the creative economy: Industry and occupational approaches. Economic Development Quarterly, 22(1), 24-45. https://doi.org/10.1177/0891242407311862

Miège, B. (1979). The cultural commodity. Media, Culture and Society, 1, 297-311. https://doi.org/10.1177/016344377900100307

Miller, T. (2009). From creative to cultural industries: Not all industries are cultural, and no industries are creative. Cultural Studies, 23(1), 88-99. https://doi.org/10.1080/09502380802326660

Mitkus, T., \& Maditinos, D. I. (2017). Analysis of state aid policy to stimulate innovation and internationalization in Lithuanian animation industry. Oeconomia Copernicana, 8(3), 433-446. https://doi.org/10.24136/oc.v8i3.27

Morin, E. (1962). L’Epstrit du temps 1: Névrose. Paris: Bernard Grasset.

Nathan, M., Pratt, A., \& Rincon-Aznar, A. (2015). Creative economy employment in the EU and the UK: A comparative analysis. Retrieved from https://www.bl.uk/collection-items/creative-economyemployment-in-the-eu-and-uk-a-comparative-analysis

Newbigin, J. (2010). The creative economy: An introductory guide. P. Rosselló \& Sh. Wright (Eds.), Series: Creative and Cultural Economy Series. Vol. 1. London: British Council.

Nurković, R. (2015). Contemporary development of creative industries in Bosnia and Herzegovina. Quaestiones Geographicae, 34(2), 45-51. https://doi.org/10.1515/quageo-2015-0014

Nwaiwu, F. (2018). Review and comparison of conceptual frameworks on digital business transformation. Journal of Competitiveness, 10(3), 86-100. https://doi.org/10.7441/joc.2018.03.06

O'Connor, J. (2009). Creative industries: A new direction?. International Journal of Cultural Policy, 15(4), 387-402. https://doi.org/10.1080/10286630903049920

O'Connor, J. (2011). The cultural and creative industries: A critical history. Ekonomiaz, 78(3), 25-45.

O'Connor, J. (2010). The cultural and creative industries: A literature review. Series: Creativity, Culture and Education Series. Newcastle upon Tyne: Creativity, Culture and Education.

Potts, J., \& Cunningham, S. (2008). Four models of the creative industries. International Journal of Cultural Policy, 14(3), 233-247. https://doi.org/10.1080/10286630802281780

Pratt, A. C. (2010). Creative cities: Tensions within and between social, cultural and economic development. A critical reading of the UK experience. City, Culture and Society, 1(1), 13-20.

https://doi.org/10.1016/j.ccs.2010.04.001 
Pratt, A. C. (2008). Creative cities: The cultural industries and the creative class. Geografiska Annaler: Series B, Human Geography, 90(2), 107-117. https://doi.org/10.1111/j.1468-0467.2008.00281.x

Pratt, A. C. (2011). The cultural contradictions of the creative city. City, Culture and Society, 2(3), 123130. https://doi.org/10.1016/j.ccs.2011.08.002

Primorac, J. (2014). The position and perspectives of cultural and creative industries in Southeastern Europe. Medijska istraživanja: znanstveno-stručni časopis za novinarstvo i medije, 20(1), 45-64.

Scott, A. J. (2006). Creative cities: Conceptual issues and policy questions. Journal of Urban Affairs, 28(1), 1-17. https://doi.org/10.1111/j.0735-2166.2006.00256.x

Skavronska, I. V. (2017). Creative industries in Ukraine: Analysis and prospects of the development. Economics and Sociology, 10(2), 87-106. https://doi.org/10.14254/2071-789X.2017/10-2/7

Spitsin, V., Mikhalchuk, A., Chistyakova, N., Spitsyna, L., \& Pavlova, I. (2018). Development of innovative industries in Russia under unfavourable external environment. Equilibrium: Quarterly Journal of Economics and Economic Policy, 13(3), 467-485. https://doi.org/10.24136/eq.2018.023

Stasiulis, N. (2017). The idea of the creative society and the development of creative industries. Economics and Sociology, 10(2), 217-226. https://doi.org/10.14254/2071-789X.2017/10-2/16

Stern, M. J., \& Seifert, S. C. (2008). From creative economy to creative society. Culture and community revitalization: A collaboration 6. University of Pennsylvania Scholarly Commons. Retrieved from https://repository.upenn.edu/cgi/viewcontent.cgi?article=1006\&context=siap_revitalization

Sułkowski, Ł. (2012). Meta-paradigmatic cognitive perspective in management studies. Argumenta Oeconomica, 2(29), 33-51.

Ślusarczyk, B. (2018). Industry 4.0 - are we ready?. Polish Journal of Management Studies, 17(1), 232248. https://doi.org/10.17512/pjms.2018.17.1.19

Štefko, R., \& Steffek, V. (2017). A study of creative industry entrepreneurial incubation. Polish Journal of Management Studies, 15(2), 250-261. https://doi.org/10.17512/pjms.2017.15.2.23

Teixeira Bento Pires, B. M. (2012). The impact of "creative industries" definitions on subsector typologies (PhD Thesis). Escola das Artes da Universidade Católica Portuguesa. Porto, Portugal. Retrieved from https://repositorio.ucp.pt/bitstream/10400.14/16571/1/The\%20impact\%20of\%20'Creative\%20 Industries'\%20definitions\%20on\%20subsector\%20typologies.pdf

Throsby, D. (2008). Modelling the cultural industries. International Journal of Cultural Policy, 14(3), 217-232. https://doi.org/10.1080/10286630802281772

Țițan, E., Voineagu, V., \& Todose, M. (2008). The impact of cultural-creative industries on the economic growth - a quantitative approach. Annals of Faculty of Economics, University og Oradea, 2(1), 930-935.

Turs'kij, I. V. (2016). Mizhnarodniy dosvid regionalnogo rozvitku kreativnikh industriy. Biznes Inform, $12,72-79$.

United Nations Conference on Trade and Development. (2008). Creative Economy: Report 2008. The challenge of assessing the Creative Economy: Towards informed policy-making. Retrieved from https:// unctad.org/en/Docs/ditc20082cer_en.pdf

United Nations Conference on Trade and Development. (2010). Creative Economy: Report 2010. Creative Economy: A feasible development option. Retrieved from https://unctad.org/en/Docs/ ditctab20103_en.pdf

United Nations Conference on Trade and Development. (2015). Creative Economy Outlook and Country Profiles: Trends in international trade in creative industries. Retrieved from https://unctad.org/en/ PublicationsLibrary/webditcted2016d5_en.pdf

United Nations Conference on Trade and Development. (2018). UNCTAD's work on the creative economy. Retrieved from https://unctad.org/en/Pages/DITC/CreativeEconomy/Creative-Economy.aspx

United Nations Conference on Trade and Development STAT. (2018). Creative economy. Data center. Retrieved from https://unctadstat.unctad.org/wds/ReportFolders/reportFolders.aspx 
United Nations Educational, Scientific and Cultural Organization. (2013). Creative Economy Report 2013. Special Edition: Widening Local Development Pathways. Retrieved from http://www.unesco. org/culture/pdf/creative-economy-report-2013.pdf

United Nations Educational, Scientific and Cultural Organization. (2017). Creative industries, creativity. Retrieved from http://www.unesco.org/new/en/culture/themes/creativity/creative-industries/

United Nations Educational, Scientific and Cultural Organization. (2012). Measuring the economic contribution of cultural industries: A review and assessment of current methodological approaches. 2009 Framework for Cultural Statistics Handbook. No. 1. Montreal: UNESCO Institute for Statistics.

Vasilyeva, T., Lyeonov, S., Adamičková, I., \& Bagmet, K. (2018a). Institutional quality of social sector: The essence and measurements. Economics and Sociology, 11(2), 248-262. https://doi.org/10.14254/2071-789X.2018/11-2/17

Vasylieva, T., Lyeonov, S., Lyulyov, O., \& Kyrychenko, K. (2018b). Macroeconomic stability and its impact on the economic growth of the country. Montenegrin Journal of Economics, 14(1), 159-170. https://doi.org/10.14254/1800-5845/2018.14-1.12

Wierzbicka, W. (2018). Information infrastructure as a pillar of the knowledge-based economy - an analysis of regional differentiation in Poland. Equilibrium: Quarterly Journal of Economics and Economic Policy, 13(1), 123-139. https://doi.org/10.24136/eq.2018.007

Working Group of EU Member States Experts (Open Method of Coordination) on Cultural and Creative Industries. (2012). Policy handbook on how to strategically use the EU support programmes, including structural funds, to foster the potential of culture for local, regional and national development and the spill-over effects on the wider economy? Retrieved from http://ec.europa.eu/assets/eac/ culture/library/publications/cci-policy-handbook_en.pdf

Yusuf, Sh., \& Nabeshima, K. (2005). Creative industries in East Asia. Cities, 22(2), 109-122. https://doi.org/10.1016/j.cities.2005.01.001

Zachorowska-Mazurkiewicz, A., \& Sierotowicz, T. (2017). Women, men and creativity in higher education sector - comparative studies of leading EU and ECE countries. Journal of International Studies, 10(3), 105-119. https://doi.org/10.14254/2071-8330.2017/10-3/8

Zelentsova, E. V. (2008). Stanovlenie i razvitie kreativnyih industriy v sovremennoy kulture: Analiz zarubezhnogo opyita (PhD Thesis). Moscow State Pedagogical University. Moscow, Russia.

Żelazny, R. (2017). Determinants and measurement of smart growth: Evidence from Poland. Journal of International Studies, 10(1), 34-45. https://doi.org/10.14254/2071-8330.2017/10-1/2

\section{KŪRYBINĖ INDUSTRIJA KAIP EKONOMIKOS PLĖTROS VEIKSNYS: EUROPIETIŠKOSIOS PATIRTIES SKLAIDA PEREINAMOJO LAIKOTARPIO EKONOMIKOS ŠALYSE}

\section{Yuriy BILAN, Tetyana VASILYEVA, Olena KRYKLII, Gulbarshyn SHILIMBETOVA}

\section{Santrauka}

Šio straipsnio tikslas - apibrèžti galimybę panaudoti Europos šalių patirtị plètojant kūrybinę industriją kaip ekonomikos augimo varomąją jègą pereinamojo laikotarpio ekonomikos šalyse. Autoriai ištyrinejo kūrybinès industrijos koncepciją, esamus kūrybos ekonomikos subsektorių klasifikavimo modelius. Straipsnyje analizuojami kūrybos industrijos pletros pasauliniai duomenys ir šių procesų bruožai pereinamojo laikotarpio ekonomikos sąlygomis. Remiantis gautais rezultatais, svarbiausios paskatos, kurioms įtakos turètų vyriausybių nutarimai pereinamojo laikotarpio 
ekonomikos sąlygomis, yra šios: užtikrinta prieiga prie lèšų, veiksmingos švietimo sistemos garantavimas visais lygmenimis, siekiant užtikrinti kvalifikuotos darbo jègos pasiekiamumą bei vartotojų raštingumas kūrybos produktų atžvilgiu, aukštos kokybès infrastruktūros ir reglamentavimo sistemos prieinamumas. Nuo šio taško rekomendacijos, skirtos kūrybinès industrijos plètrai pereinamojo laikotarpio ekonomikos sąlygomis, struktūruojamos atsižvelgiant ị pagrindines suinteresuotąsias šalis: valdžią, vietos vyriausybę (regionai ir miestai), aukštojo mokslo institucijas, kūrybinę industriją ir kitus verslo atstovus.

Reikšminiai žodžiai: kūrybinių industrijų klasifikacija, kūrybos ekonomika, kūrybinès industrijos, pereinamojo laikotarpio ekonomika. 